DOI: $10.20472 /$ IAC.2019.050.017

\title{
TOMISLAV HERCEG
}

Faculty of Economics and Busines, University of Zagreb, Croatia

\section{IVA VUKSANOVIĆ HERCEG}

Faculty of Economics, University of Belgrade, Serbia

FRAN GALETIĆ

Faculty of Economics and Busines, University of Zagreb, Croatia

\section{EFFECTS OF EMIGRATION ON CROATIAN GROWTH AND PENSION FUND SUSTAINABILITY PROSPECTS}

\begin{abstract}
:
This paper analyses the current depopulation with respect to its impact on the labour market in Croatia and brings it into relation with the prospective of economic growth and sustainability of Croatian pension funds. Taking this situation as a starting point for further surveys, authors present an analysis of the systemic risk with respect to the population trends and input substitution driven growth.

The first part of the survey shows that population trends in Croatia are detrimental: high emigration and low birth rate, resulting in an 7\% fall in Croatian population since EU accession in 2013. Two different scenarios are used to make simulations of a population projection, revealing that under current conditions ( $0,9 \%$ birth rate and $0,33 \%$ net emigration rate) Croatia would lose 1 Million people (1 quarter) in 3 decades and more retired people than those employed. In the other scenario, under which Croatia would maintain stable population volume, a birth rate of $1,5 \%$ would be required, which means that birth count should increase by $67 \%$. Even in that case it would take more than 2 decades to overturn the negative trend and 35 years to match current employed/retired ratio of 1,2 .

The second part puts the previous simulations into relation with pension fund sustainability. A simulation has shown that under an adaptive (pessimistic) scenario pension fund would require additional $12,8 \%$ of the state budget to be able to pay pensions since then there would be $10 \%$ more retired than employed people. Even in a sustainable (optimistic) scenario a state budget could expect a fall in the pension fund intervention in 30 years from now.

The third part makes some growth accounting analysis. Although majority of the studies take the number of workers as constant since it varies very little in the short run, in Croatia there is a tendency of a rather hasty change in a population and workforce. It brings to conclusion that the changes in labour are not to be ignored and, if the countries want to maintain some minimum growth rates, the decrease in labour will have to be compensated by other factors, such as the increase in stocks of capital through investments and incentives for technology improvement. A simulation has shown that a country which has a fall in workforce of 1\% per annum (in Croatia in 2018 it was $-1,23 \%$ ) the investments share in GDP should increase by $8 \%$, making it a very costly and hardly achievable option.
\end{abstract}

\section{Keywords:}

Total Fertility Rate, Emigration, Growth Accounting, Generation Solidarity Pension System, Overlapping Generation Model 
JEL Classification: J11, J21, H55 


\section{Introduction}

Pension system in Croatia relies on "generation solidarity", a system developed in the socialist Yugoslavia after WWII. It was necessary to introduce such a system due to many war veterans receiving pensions from the state. However, such system can work only if fertility rate is above replacement level. According to Wertheimer-Baletic (2017), it is not only 2.2 which is the most commonly used, which includes biological impediments for reproduction, but even higher, 2.38, due to voluntary celibacy.

Figure 1 shows fertility rate from 1950 onwards. A downward trend of total fertility rate (TFR) has slowed down at the average level of 1.4 which is far below a replacement level - in 1957 Croatian TFR has fallen below 2.38 threshold and in 1960 even below biological replacement level of 2.2. Therefore a steady and long-term below replacement level of TFR lasts for 59 years now, which means that in a 6 years, a generation that had a below replacement level of TFR, would get retired. It shows that Croatian pension system is at a huge risk even without emigration which is immense.

\section{Figure 1: Fertility rate in Croatia, 1950-2017}

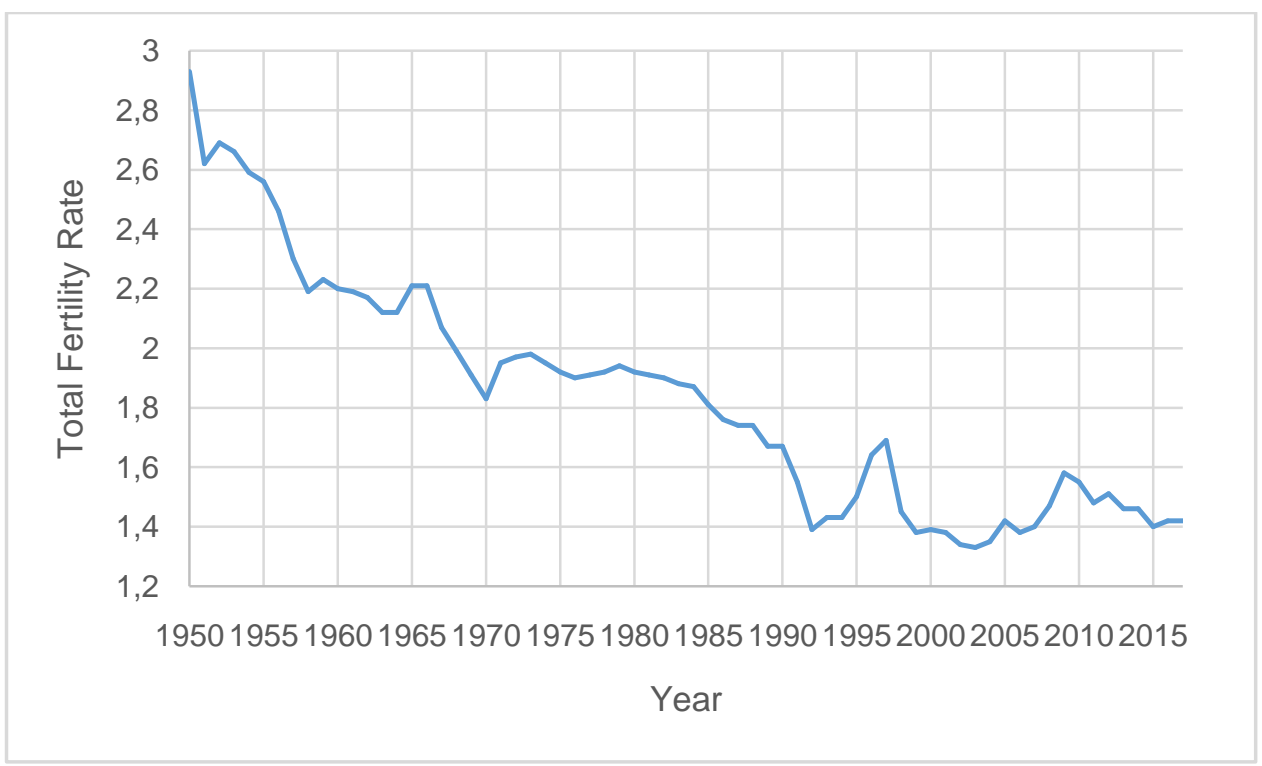

Source of data: Eurostat

The other European countries have faced the same problem in 1960 s too, facing fertility rate below 2.2. (Figure 2).

Table 1: Fertility rates across Europe in 2017

\begin{tabular}{|l|c|l|c|}
\hline & $\begin{array}{l}\text { Total } \\
\text { fertility } \\
\text { rate }\end{array}$ & Country & $\begin{array}{l}\text { Total } \\
\text { fertility } \\
\text { rate }\end{array}$ \\
\hline Belgium & 1,65 & Malta & 1,26 \\
\hline Bulgaria & 1,56 & Netherlands & 1,62 \\
\hline Czechia & 1,69 & Austria & 1,52 \\
\hline Denmark & 1,75 & Poland & 1,48 \\
\hline
\end{tabular}




\begin{tabular}{|l|c|l|c|}
\hline Country & $\begin{array}{l}\text { Total } \\
\text { fertility } \\
\text { rate }\end{array}$ & Country & $\begin{array}{l}\text { Total } \\
\text { fertility } \\
\text { rate }\end{array}$ \\
\hline Germany & 1,57 & Portugal & 1,38 \\
\hline Estonia & 1,59 & Romania & 1,71 \\
\hline Ireland & 1,77 & Slovenia & 1,62 \\
\hline Greece & 1,35 & Slovakia & 1,52 \\
\hline Spain & 1,31 & Finland & 1,49 \\
\hline France & 1,90 & Sweden & 1,78 \\
\hline Croatia & 1,42 & United Kingdom & 1,74 \\
\hline Italy & 1,32 & Norway* & 1,62 \\
\hline Cyprus & 1,32 & Switzerland & 1,52 \\
\hline Latvia & 1,69 & Montenegro* & 1,78 \\
\hline Lithuania & 1,63 & North & Macedonia* \\
\cline { 2 - 5 } & 1,43 \\
\hline Luxembourg & 1,39 & Albania* $^{*}$ & 1,48 \\
\hline Hungary & 1,54 & Serbia* $^{*}$ & 1,49 \\
\hline
\end{tabular}

Source of data: Eurostat

Up to date no European country has recovered their fertility rates, except in those where immigrants rise it (Frejka, Sobotka, 2008), like in France and United Kingdom. Projections for the future indicate that this depopulation trend will only continue to grow. Chand and Jaeger (1996) have warned many countries with a similar generation solidarity system about the future of that system and its weight on the state budget. Up till today, they have been dangerously correct in their predictions.

Fertility rate is important for the economy in three stages: expenses of the state to educate and provide health care for young people tax collection when the y become working age population, and finally expenses for health care and pensions (where a system relies on generation solidarity). Therefore low fertility rate shows its negative effects about two decades after it falls down from a replacement level. At that moment an economic contraction could appear unless a country has ways how to substitute for labour force contraction, in terms of capital deepening and technology improvement. Also, there is a possibility for labour force importation which carries risks of a cultural melting pot. To sum up, in the first and the last stage a country has expenses and in the second the revenues that cover for the expenses of the population that appear before or after their working age and should at least match those expenses. However, unbalanced fertility causes the unbalance between those three groups.

Emigration is far more dangerous for an economy than natural ageing of population. Out of the above mentioned stages, the emigrating population stays in the economy only for duration of the first and a small part of the second stage, thus leaving the country only with the expenses.

The purpose of this paper is to evaluate the economic effects of depopulation in Croatia, caused by both low fertility and emigration, especially those on a pension system. There is a number of direct and indirect factors that affect sustainability of the generation solidarity pension system. Direct one is low employed/retired ratio which in turns requires the state to fill the gaps of the pension fund more and more. Indirect factor is the fact that pensions are related to the salaries, which are related to the GDP per capita, not GDP. But since GDP is about to slow down due to 
the fall in the workforce, the ratio of pensions in GDP would rise, requiring increasing share of the state budget for the system to operate. Therefore in order to maintain GDP growth level, a substitution of labour with capital and technology should occur. However, since labour accounts for greater part of GDP creation, a country has to increase stocks of capital and technology improvement by far greater growth rates in order to catch up with demographic decline.

The problems listed above determine the following sections of this paper. Firstly, an analysis of the natural and migrational decline of population in Croatia is made, with simulation for the future in two scenarios: a pessimistic, based on the current data, and a necessary one, that would maintain at least the current level of population. Secondly, an analysis of the current Croatian pension system (in)balance with simulation in both of the previously mentioned scenarios. Finally, an application of the simple model applying growth accounting methods would show what could be done even in the pessimistic scenario, by substituting labour with capital deepening and total factor productivity growth.

\section{Croatian population trends}

Croatian pension system (Croatian: Hrvatski zavod za mirovinsko osiguranje, or HZMO) is a state-owned system based on generation solidarity, meaning that people who pay their (obligatory) retirement insurance finance pensions of the currently retired. This system is good for a growing, young population, like Croatia in a time when the system was introduced shorty after World War II, but today it shows its downsides in a situation when the number of kids from $0-4$ is almost identical to number of people aged from $70-74$ (Figure 2). Similar situation was faced by many other countries with a generation solidarity system (Fanti, Gori, 2012).

Table 2: Population, emigration and deaths by age group in Croatia in 2016

\begin{tabular}{|r|r|r|r|r|r|r|r|}
\hline $\begin{array}{c}\text { Age } \\
\text { group }\end{array}$ & $\begin{array}{c}\text { Number } \\
\text { of } \\
\text { deaths }\end{array}$ & $\begin{array}{r}\text { Number } \\
\text { of people }\end{array}$ & $\begin{array}{c}\% \text { of } \\
\text { Population } \\
\text { That Dies } \\
\text { in a Year }\end{array}$ & $\begin{array}{c}\text { Share of Age } \\
\text { Groups in } \\
\text { Number of } \\
\text { Deaths }\end{array}$ & $\begin{array}{c}\text { Net } \\
\text { Emigrants }\end{array}$ & $\begin{array}{c}\text { Population } \\
\text { That Net } \\
\text { Emigrates in a } \\
\text { Year }\end{array}$ & $\begin{array}{c}\text { Share of Age } \\
\text { Groups in } \\
\text { Emigration }\end{array}$ \\
\hline $0-4$ & 130 & 198.479 & $0,065 \%$ & $0,252 \%$ & 1.504 & $0,758 \%$ & $4,730 \%$ \\
\hline $5-9$ & 76 & 210.855 & $0,036 \%$ & $0,147 \%$ & 2.442 & $1,158 \%$ & $7,679 \%$ \\
\hline $10-14$ & 50 & 202.138 & $0,025 \%$ & $0,097 \%$ & 1.910 & $0,945 \%$ & $6,006 \%$ \\
\hline $15-19$ & 51 & 235.643 & $0,022 \%$ & $0,099 \%$ & 1.336 & $0,567 \%$ & $4,201 \%$ \\
\hline $20-24$ & 100 & 243.706 & $0,041 \%$ & $0,194 \%$ & 2.651 & $1,088 \%$ & $8,337 \%$ \\
\hline $25-29$ & 113 & 260.048 & $0,043 \%$ & $0,219 \%$ & 4.667 & $1,795 \%$ & $14,677 \%$ \\
\hline $30-34$ & 213 & 286.283 & $0,074 \%$ & $0,413 \%$ & 4.445 & $1,553 \%$ & $13,978 \%$ \\
\hline $35-39$ & 203 & 289.461 & $0,070 \%$ & $0,394 \%$ & 3.797 & $1,312 \%$ & $11,941 \%$ \\
\hline $40-44$ & 428 & 277.531 & $0,154 \%$ & $0,830 \%$ & 2.850 & $1,027 \%$ & $8,963 \%$ \\
\hline $45-49$ & 665 & 281.578 & $0,236 \%$ & $1,290 \%$ & 2.461 & $0,874 \%$ & $7,739 \%$ \\
\hline $50-54$ & 1523 & 299.268 & $0,509 \%$ & $2,955 \%$ & 1.715 & $0,573 \%$ & $5,393 \%$ \\
\hline $55-59$ & 2046 & 308.195 & $0,664 \%$ & $3,970 \%$ & 873 & $0,283 \%$ & $2,745 \%$ \\
\hline $60-64$ & 3123 & 292.599 & $1,067 \%$ & $6,059 \%$ & 414 & $0,141 \%$ & $1,302 \%$ \\
\hline $65-69$ & 4936 & 245.762 & $2,008 \%$ & $9,577 \%$ & 286 & $0,116 \%$ & $0,899 \%$ \\
\hline $70-74$ & 5422 & 181.057 & $2,995 \%$ & $10,520 \%$ & 297 & $0,164 \%$ & $0,934 \%$ \\
\hline
\end{tabular}




\begin{tabular}{|r|r|r|r|r|r|r|r|}
\hline $\begin{array}{c}\text { Age } \\
\text { group }\end{array}$ & $\begin{array}{c}\text { Number } \\
\text { of } \\
\text { deaths }\end{array}$ & $\begin{array}{r}\text { Number } \\
\text { of people }\end{array}$ & $\begin{array}{c}\text { \% of } \\
\text { Population } \\
\text { That Dies } \\
\text { in a Year }\end{array}$ & $\begin{array}{c}\text { Share of Age } \\
\text { Groups in } \\
\text { Number of } \\
\text { Deaths }\end{array}$ & $\begin{array}{c}\text { Net } \\
\text { Emigrants }\end{array}$ & $\begin{array}{c}\text { of Population } \\
\text { That Net } \\
\text { Emigrates in a } \\
\text { Year }\end{array}$ & $\begin{array}{c}\text { Share of Age } \\
\text { Groups in } \\
\text { Emigration }\end{array}$ \\
\hline $75-79$ & 7511 & 175.853 & $4,271 \%$ & $14,573 \%$ & 70 & $0,040 \%$ & $0,220 \%$ \\
\hline $80-84$ & 6242 & 124.352 & $5,020 \%$ & $12,111 \%$ & 50 & $0,040 \%$ & $0,157 \%$ \\
\hline $85+$ & 13351 & 77.861 & 17,147 & $25,903 \%$ & 31 & $0,040 \%$ & $0,097 \%$ \\
\hline Total & $\mathbf{5 1 . 5 4 2}$ & $\mathbf{4 . 1 9 0 . 6 6 9}$ & $\mathbf{1 , 2 3 0} \%$ & $\mathbf{1 0 0 , 0 0 0} \%$ & $\mathbf{3 1 . 7 9 9}$ & $\mathbf{0 , 7 5 9 \%}$ & $\mathbf{1 0 0 , 0 0 0 \%}$ \\
\hline
\end{tabular}

Sources - Own calculation based on data from Eurostat, Hrvatski zavod za mirovinsko osigranje and Državni zavod za statistiku

Furthermore, a number of young people entering the workforce aged from $0-19$ is the same as the number of people older than 64 who are out of the workforce. When observing the trends in the numbers of people in each age group, it can be seen that the situation continues to aggravate (Table 3).

\section{Table 3: Population per age groups in Croatia}

\begin{tabular}{|r|r|r|r|r|r|r|}
\hline & $\mathbf{2 0 1 3}$ & $\mathbf{2 0 1 4}$ & $\mathbf{2 0 1 5}$ & $\mathbf{2 0 1 6}$ & $\mathbf{2 0 1 7}$ & $\mathbf{2 0 1 8}$ \\
\hline $0-4$ & 213.236 & 209.819 & 205.161 & 198.479 & 194.002 & 187.931 \\
\hline $5-9$ & 205.124 & 207.846 & 211.122 & 210.855 & 208.924 & 207.127 \\
\hline $10-14$ & 218.179 & 209.973 & 204.767 & 202.138 & 200.524 & 199.335 \\
\hline $15-19$ & 246.638 & 245.481 & 241.956 & 235.643 & 224.781 & 213.583 \\
\hline $20-24$ & 253.700 & 249.756 & 246.590 & 243.706 & 241.706 & 241.994 \\
\hline $25-29$ & 280.121 & 275.367 & 266.817 & 260.048 & 254.011 & 244.211 \\
\hline $30-34$ & 295.228 & 294.016 & 291.402 & 286.283 & 278.209 & 268.395 \\
\hline $35-39$ & 285.591 & 286.813 & 288.558 & 289.461 & 288.189 & 284.436 \\
\hline $40-44$ & 279.410 & 277.716 & 276.652 & 277.531 & 276.363 & 274.764 \\
\hline $45-49$ & 301.899 & 297.619 & 292.380 & 281.578 & 274.327 & 268.827 \\
\hline $50-54$ & 314.279 & 309.449 & 303.185 & 299.268 & 295.726 & 290.149 \\
\hline $55-59$ & 316.451 & 315.155 & 312.206 & 308.195 & 304.126 & 300.862 \\
\hline $60-64$ & 279.143 & 285.115 & 289.373 & 292.599 & 299.063 & 298.518 \\
\hline $65-69$ & 206.829 & 213.740 & 228.050 & 245.762 & 251.335 & 256.892 \\
\hline $70-74$ & 206.745 & 201.716 & 192.999 & 181.057 & 181.592 & 183.678 \\
\hline $75-79$ & 177.573 & 177.305 & 176.934 & 175.853 & 172.911 & 171.524 \\
\hline $80-84$ & 115.735 & 119.868 & 123.084 & 124.352 & 126.413 & 127.663 \\
\hline $85+$ & 66.259 & 70.055 & 74.080 & 77.861 & 82.011 & 85.604 \\
\hline Total & 4.262 .140 & $\mathbf{4 . 2 4 6 . 8 0 9}$ & 4.225 .316 & $\mathbf{4 . 1 9 0 . 6 6 9}$ & $\mathbf{4 . 1 5 4 . 2 1 3}$ & $\mathbf{4 . 1 0 5 . 4 9 3}$ \\
\hline
\end{tabular}

Source - Own calculation based on data from Državni zavod za statistiku

The data reveals a continuous fall in the newly born, while people entering retirement age (65) continues to grow, 
The reason for it lies in two factors: decades of the below replacement level total fertility rate (Figure 1) and negative migration trends, since Croatia has been emigrating since the late $19^{\text {th }}$ century up till modern days. Emigration has happened in several waves: due to vine grape disease in the late $19^{\text {th }}$ century many have emigrated to the Americas; in the period between WWI and WWII due to famine; immediately after WWII because of the communism, mostly to Americas and Western Europe; during 60's to Germany as guest workers, after 1972 because of the Croatian independence claims, during a "lost decade" (80's) to Germany and Switzerland, during war in the 90's and finally today, just after the accession to EU. The depth of the latter can be seen on the Figure 2.

Figure 2: Rates of net migration, natural and total population change in Croatia, 1960-2018

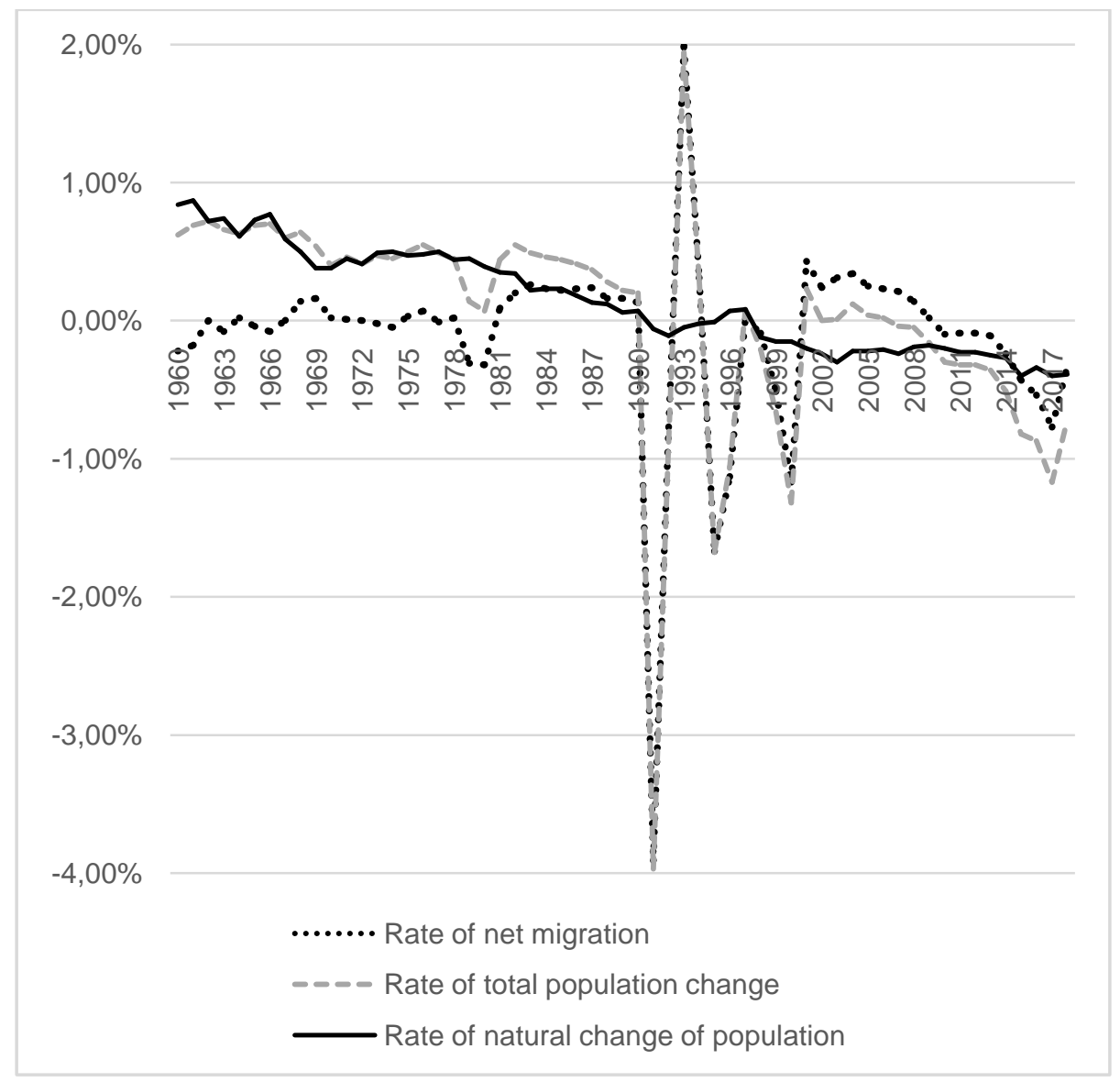

Sources of data: Eurostat and Hrvatski zavod za statistiku

Figure 2 reveals two very important and detrimental trends: continuous fall in the rate of natural change in population which dropped below 0 in the 90's, and rate of net migration which since the year 2000 continuously drops down and falls below zero at the dawn of the Great recession in 2008. For over a decade now Croatia has both rates negative, for the first time in its history. ${ }^{1}$

\footnotetext{
${ }^{1}$ Wang, Yip and Scotese (1994) have used fetility rate instead of birth rate, which is more thorough, but unreasonably more complex for modelling
} 
In order to estimate future development of Croatian population, the following simulation is made (overlapping generation model): population of each 5 - year age group, starting from 2018, is projected onto 5 - year periods in the future, until 2053. 5 - year time gaps enable use of public statistic age groups, where for example age group from 0 - 5 in 2018 becomes population of 5 10 years in 2023, but fixed for two factors: death rate for each age group, and emigration tendency of each age group, all based on Croatia in 2016 (years 2013 - 2017 yield the same results and could have been key for projections as well). The data used is provided in the Table 2 (\% of Population That Dies in a Year and \% of Population That Net Emigrates in a Year).

Since rate of emigration is under exterior influences, one needs to analyze how a different emigration rate affects population in the future. Therefore it is assumed that emigration rate is distributed in the same proportions among the groups as it was in 2016. For example, the age group 15-19 had the emigration proportion at 0,025\%, and total emigration rate was $0,759 \%$ in the same year. If one assumes that total emigration would be, say, $1 \%$, since $1 / 0,759=1,318$, a $15-19$ age group proportion of emigration would be $0,025 \% \times 1,318=0,033 \%$. This kind of observation requires introduction of an exogenous emigration rate by which one could estimate long - term population level.

The other rate, death rate per group, is exogenous and mostly given, since it is rather identical to those of the Western European countries (based on own calculation using Eurostat data). However, there is a rate that affects population level but can be incited by various factors. It is birth rate: Therefore an exogenous variable is introduced, a birth rate, which determines the number of people in the $0-5$ age group in the each of 5 - year projection intervals from 2018 2053.

Using the previously mentioned projection model, two scenarios are analyzed. One is based on the rates which would maintain the current population volume. The other is based on emigration and birth rate which is currently present. The first projection is given with the Table 4, which analyzes a stable population case (sustainable scenario). It was found that stable population level is maintained at $1,5 \%$ birth rate under $0 \%$ net emigration rate. If an immigration case would occur, birth rate could be lower. On the other hand, if there would be a net emigration, the birth rate should be above $1,5 \%$.

Table 4: Population projection per age groups in Croatia - sustainable scenario

\begin{tabular}{|r|r|r|r|r|r|r|r|r|}
\hline & $\begin{array}{l}\text { Number of } \\
\text { people in } \\
\mathbf{2 0 1 8}\end{array}$ & $\begin{array}{l}\text { Number of } \\
\text { people in } \\
\mathbf{2 0 2 3}\end{array}$ & $\begin{array}{l}\text { Number of } \\
\text { people in } \\
\mathbf{2 0 2 8}\end{array}$ & $\begin{array}{l}\text { Number of } \\
\text { people in } \\
\mathbf{2 0 3 3}\end{array}$ & $\begin{array}{l}\text { Number of } \\
\text { people in } \\
\mathbf{2 0 3 8}\end{array}$ & $\begin{array}{l}\text { Number of } \\
\text { people in } \\
\mathbf{2 0 4 3}\end{array}$ & $\begin{array}{l}\text { Number of } \\
\text { people in } \\
\mathbf{2 0 4 8}\end{array}$ & $\begin{array}{l}\text { Number of } \\
\text { people in } \\
\mathbf{2 0 5 3}\end{array}$ \\
\hline $0-4$ & 198.479 & 314.300 & 310.481 & 309.194 & 309.414 & 309.070 & 308.570 & 308.565 \\
\hline $5-9$ & 210.855 & 198.121 & 313.734 & 309.921 & 308.637 & 308.856 & 308.513 & 308.014 \\
\hline $10-14$ & 202.138 & 210.594 & 197.876 & 313.346 & 309.538 & 308.255 & 308.474 & 308.131 \\
\hline $15-19$ & 235.643 & 201.919 & 210.366 & 197.662 & 313.007 & 309.203 & 307.921 & 308.140 \\
\hline $20-24$ & 243.706 & 235.160 & 201.505 & 209.934 & 197.256 & 312.365 & 308.569 & 307.289 \\
\hline $25-29$ & 260.048 & 243.177 & 234.649 & 201.067 & 209.478 & 196.827 & 311.686 & 307.899 \\
\hline $30-34$ & 286.283 & 259.081 & 242.272 & 233.776 & 200.319 & 208.699 & 196.095 & 310.526 \\
\hline $35-39$ & 289.461 & 285.279 & 258.173 & 241.422 & 232.956 & 199.617 & 207.967 & 195.407 \\
\hline $40-44$ & 277.531 & 287.229 & 283.079 & 256.182 & 239.560 & 231.160 & 198.078 & 206.363 \\
\hline
\end{tabular}




\begin{tabular}{|c|c|c|c|c|c|c|c|c|}
\hline Age group & $\begin{array}{l}\begin{array}{l}\text { Number of } \\
\text { people in } \\
2018\end{array} \\
\end{array}$ & $\begin{array}{l}\text { Number of } \\
\text { people in } \\
2023\end{array}$ & $\begin{array}{l}\text { Number of } \\
\text { people in } \\
2028\end{array}$ & $\begin{array}{l}\text { Number of } \\
\text { people in } \\
2033\end{array}$ & $\begin{array}{l}\text { Number of } \\
\text { people in } \\
2038\end{array}$ & $\begin{array}{l}\text { Number of } \\
\text { people in } \\
2043\end{array}$ & $\begin{array}{l}\text { Number of } \\
\text { people in } \\
2048\end{array}$ & $\begin{array}{l}\text { Number of } \\
\text { people in } \\
2053\end{array}$ \\
\hline $45-49$ & 281.578 & 274.254 & 283.837 & 279.736 & 253.157 & 236.731 & 228.430 & 195.739 \\
\hline $50-54$ & 299.268 & 274.413 & 267.275 & 276.615 & 272.618 & 246.715 & 230.707 & 222.618 \\
\hline $55-59$ & 308.195 & 289.334 & 265.304 & 258.403 & 267.433 & 263.569 & 238.526 & 223.049 \\
\hline $60-64$ & 292.599 & 291.748 & 273.893 & 251.146 & 244.613 & 253.161 & 249.503 & 225.797 \\
\hline $65-69$ & 245.762 & 263.216 & 262.450 & 246.388 & 225.925 & 220.048 & 227.738 & 224.447 \\
\hline $70-74$ & 181.057 & 208.964 & 223.804 & 223.153 & 209.496 & 192.097 & 187.100 & 193.638 \\
\hline $75-79$ & 175.853 & 142.391 & 164.338 & 176.009 & 175.497 & 164.756 & 151.073 & 147.143 \\
\hline $80-84$ & 124.352 & 131.717 & 106.654 & 123.092 & 131.834 & 131.451 & 123.405 & 113.157 \\
\hline $85+$ & 77.861 & 28.843 & 22.902 & 18.480 & 20.194 & 21.685 & 21.843 & 20.718 \\
\hline $\begin{array}{l}\text { Total } \\
\text { population }\end{array}$ & 4.190 .669 & 4.139 .740 & 4.122 .592 & 4.125 .526 & ; 4.120 .932 & 4.114.265 & 4.114.198 & 4.126 .640 \\
\hline $\begin{array}{l}\text { projected } \\
\text { E/R }\end{array}$ & 1,20 & 1,20 & 1,13 & 1,07 & 1,05 & 1,12 & 1,16 & 1,19 \\
\hline
\end{tabular}

Source - Own model based on data from Državni zavod za statistiku, Eurostat and Hrvatski zavod za mirovinsko osiguranje

Even a birth rate of $1,5 \%$ (or $15 \%$ which is more common notation when speaking about birth and death rate) could not immediately stop the fall in the total population, but in 25 years when that "baby boom" generation would come of age a recovery could be seen. Projected employed per retired ratio $(E / R)$, assuming current very low activity rate in Croatia at $38 \%$ only, would start to recover a bit sooner, in 2043, but even in 35 years from now it would be slightly lower than today. This is an optimistic scenario, in which birth rate would be increased immediately from $0,9 \%$ to $1,5 \%$ (67\% increase), which renders this scenario a virtually impossible one.

An adaptive scenario is based on the Croatian data for 2018 (mapped in Figure 2), when rate of net emigration was $0,33 \%$ and birth rate of $0,9 \%$. The projections are in the Table 5 .

Table 5: Population projection per age groups in Croatia - adaptive scenario

\begin{tabular}{|l|l|l|l|l|l|l|l|l|}
\hline & $\begin{array}{l}\text { Number } \\
\text { of people } \\
\text { in 2018 }\end{array}$ & $\begin{array}{l}\text { Number } \\
\text { of people } \\
\text { in 2023 }\end{array}$ & $\begin{array}{l}\text { Number } \\
\text { of people } \\
\text { in 2028 }\end{array}$ & $\begin{array}{l}\text { Number } \\
\text { of people } \\
\text { in 2033 }\end{array}$ & $\begin{array}{l}\text { Number } \\
\text { of people } \\
\text { in 2038 }\end{array}$ & $\begin{array}{l}\text { Number } \\
\text { of people } \\
\text { in 2043 }\end{array}$ & $\begin{array}{l}\text { Number } \\
\text { of people } \\
\text { in 2048 }\end{array}$ & $\begin{array}{l}\text { Number } \\
\text { of people } \\
\text { in 2053 }\end{array}$ \\
\hline $0-4$ & 198.479 & 185.473 & 174.460 & 164.903 & 156.175 & 147.039 & 137.754 & 128.727 \\
\hline $5-9$ & 210.855 & 194.851 & 182.083 & 171.271 & 161.889 & 153.321 & 144.351 & 135.236 \\
\hline $10-14$ & 202.138 & 205.284 & 189.703 & 177.273 & 166.746 & 157.612 & 149.270 & 140.537 \\
\hline $15-19$ & 235.643 & 197.766 & 200.844 & 185.600 & 173.439 & 163.140 & 154.203 & 146.041 \\
\hline $20-24$ & 243.706 & 232.255 & 194.922 & 197.956 & 182.931 & 170.945 & 160.794 & 151.986 \\
\hline $25-29$ & 260.048 & 237.412 & 226.256 & 189.887 & 192.844 & 178.207 & 166.531 & 156.642 \\
\hline $30-34$ & 286.283 & 248.933 & 227.264 & 216.584 & 181.771 & 184.601 & 170.590 & 159.412 \\
\hline $35-39$ & 289.461 & 275.613 & 239.655 & 218.794 & 208.513 & 174.997 & 177.721 & 164.233 \\
\hline $40-44$ & 277.531 & 278.973 & 265.627 & 230.971 & 210.866 & 200.957 & 168.656 & 171.282 \\
\hline
\end{tabular}




\begin{tabular}{|l|r|r|r|r|r|r|r|r|}
\hline & $\begin{array}{l}\text { Number } \\
\text { of people } \\
\text { in 2018 }\end{array}$ & $\begin{array}{l}\text { Number } \\
\text { of people } \\
\text { in 2023 }\end{array}$ & $\begin{array}{l}\text { Number } \\
\text { of people } \\
\text { in 2028 }\end{array}$ & $\begin{array}{l}\text { Number } \\
\text { of people } \\
\text { in 2033 }\end{array}$ & $\begin{array}{l}\text { Number } \\
\text { of people } \\
\text { in 2038 }\end{array}$ & $\begin{array}{l}\text { Number } \\
\text { of people } \\
\text { in 2043 }\end{array}$ & $\begin{array}{l}\text { Number } \\
\text { of people } \\
\text { in 2048 }\end{array}$ & $\begin{array}{l}\text { Number } \\
\text { of people } \\
\text { in 2053 }\end{array}$ \\
\hline $45-49$ & 281.578 & 268.057 & 269.450 & 256.559 & 223.086 & 203.667 & 194.097 & 162.898 \\
\hline $50-54$ & 299.268 & 269.062 & 256.142 & 257.473 & 245.155 & 213.169 & 194.614 & 185.469 \\
\hline $55-59$ & 308.195 & 285.605 & 256.778 & 244.448 & 245.719 & 233.963 & 203.437 & 185.729 \\
\hline $60-64$ & 292.599 & 289.850 & 268.604 & 241.493 & 229.897 & 231.093 & 220.036 & 191.327 \\
\hline $65-69$ & 245.762 & 262.316 & 259.851 & 240.804 & 216.499 & 206.103 & 207.175 & 197.262 \\
\hline $70-74$ & 181.057 & 208.342 & 222.375 & 220.285 & 204.139 & 183.534 & 174.721 & 175.630 \\
\hline $75-79$ & 175.853 & 141.745 & 163.106 & 174.092 & 172.455 & 159.815 & 143.684 & 136.785 \\
\hline $80-84$ & 124.352 & 131.565 & 106.047 & 122.028 & 130.247 & 129.023 & 119.566 & 107.498 \\
\hline $85+$ & 77.861 & 28.734 & 22.750 & 18.278 & 19.906 & 21.304 & 21.329 & 19.992 \\
\hline $\begin{array}{l}\text { Total } \\
\text { population }\end{array}$ & $\mathbf{4 . 1 9 0 . 6 6 9}$ & $\mathbf{3 . 9 4 1 . 8 3 6}$ & $\mathbf{3 . 7 2 5 . 9 1 7}$ & $\mathbf{3 . 5 2 8 . 6 9 9}$ & $\mathbf{3 . 3 2 2 . 2 7 7}$ & $\mathbf{3 . 1 1 2 . 4 9 0}$ & $\mathbf{2 . 9 0 8 . 5 2 9}$ & $\mathbf{2 . 7 1 6 . 6 8 6}$ \\
\hline $\begin{array}{l}\text { projected } \\
\text { E/R }\end{array}$ & $\mathbf{1 , 2 0}$ & $\mathbf{1 , 1 7}$ & $\mathbf{1 , 0 8}$ & $\mathbf{1 , 0 1}$ & $\mathbf{0 , 9 8}$ & $\mathbf{0 , 9 7}$ & $\mathbf{0 , 9 4}$ & $\mathbf{0 , 9 1}$ \\
\hline
\end{tabular}

Source - Own model based on data from Državni zavod za statistiku, Eurostat and Hrvatski zavod za mirovinsko osiguranje

This projection shows a severe fall in the total population, with a very dangerous trait of the continuously falling E/R ratio. Just after 2033 it would fall below 1, meaning that there would be more retired people than those who work. Figure 3 shows comparisons between scenarios.

Figure 3: Simulation of population and E/R ratio in Croatia for 2018 - 2053

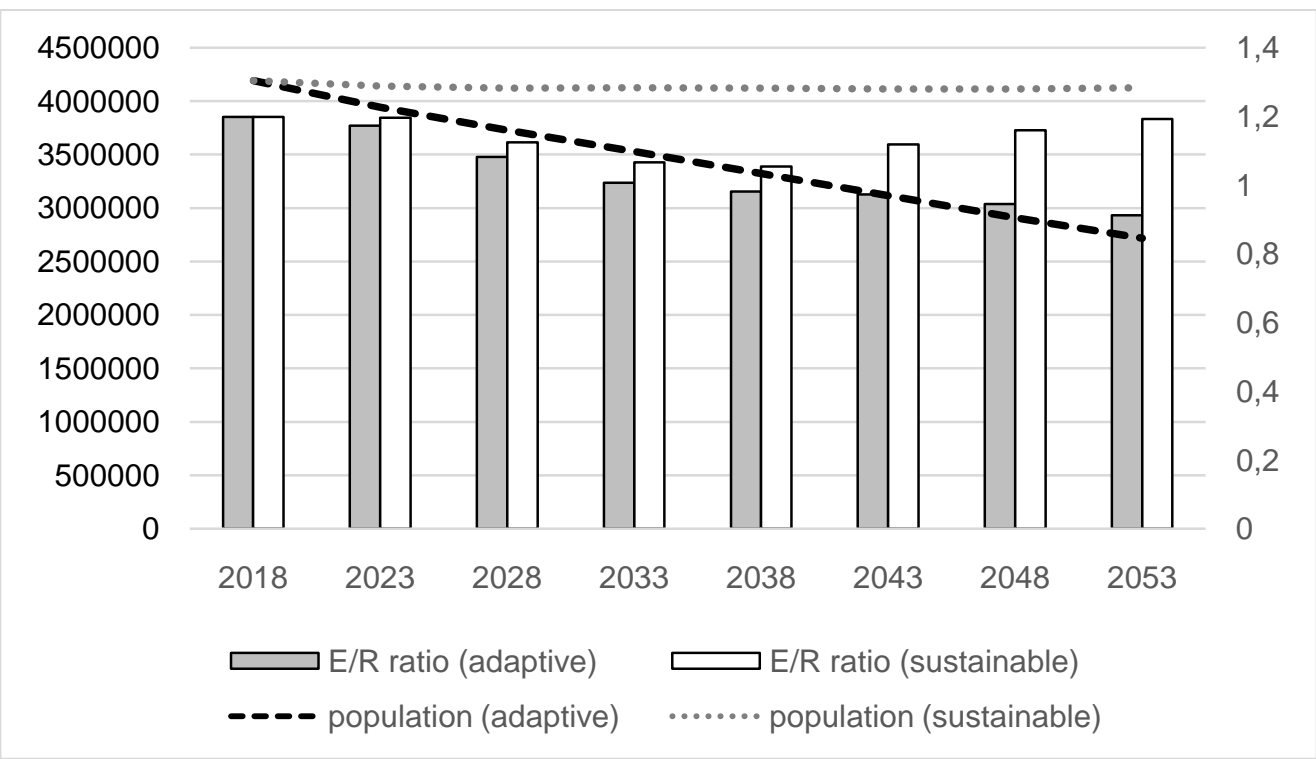

Source - Own model based on data from Državni zavod za statistiku, Eurostat and Hrvatski zavod za mirovinsko osiguranje

The figure shows that even in the sustainability scenario a gap of 25 years of a low empled/retired ratio persists which would be hard to finance. 


\section{Croatian pension system: history and perspective}

Croatian pension fund (Hrvatski zavod za mirovinsko osiguranje - HZMO) was found in 1922, but since 1946 it became a state owned generation solidarity system where pensions of the current retired people are financed by the current employed people through their retirement insurance which is obligatory. Gross salary in Croatia consists of $17,6 \%$ of retirement insurance, $14,2 \%$ of health and unemployment insurance and the rest is the gross income which is then taxed. However, since 1990's, pension fund became unable to finance pensions due to sever drop in employment during deindustrialization and war period Figure 4, left axis and bars), below replacement level of fertility rate and early retirement (55 for women, 60 for men) which resulted in the poor E/R ratio (Figure 4, right axis and curve). Even though retirement age was slowly increased up to present 65 years for both sexes, retirement insurance covers only a bit above half of pensions paid in Croatia (Table 6).

Figure 4: Employment and employed per retired ratio in Croatia, 1995-2018

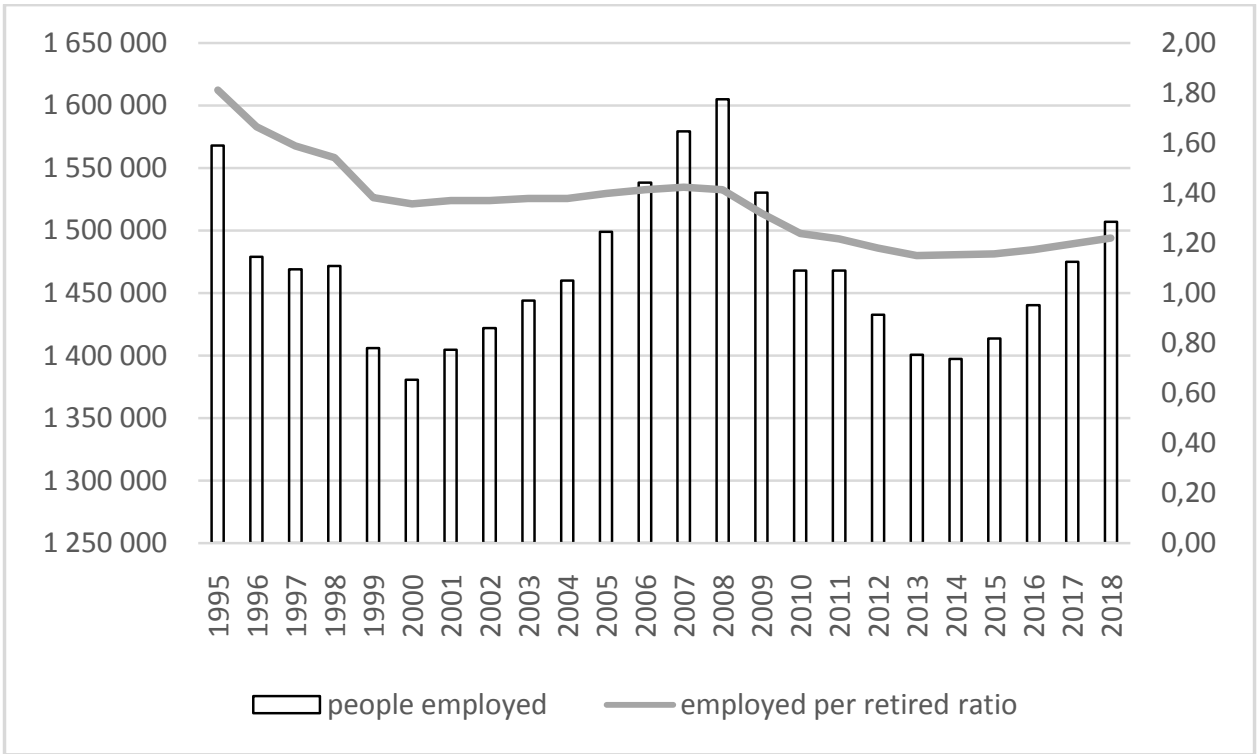

Source - Own calculation based on data from Eurostat and Hrvatski zavod za mirovinsko osiguranje

Taking the average in the last decade, based on the data from Table 6 , it can be found that retirement insurance covers only $56,3 \%$ of the pensions. The rest was financed by the state budget. It was all due to the low Employed/Retired (E/R) ratio. Therefore, since $56,3 \%$ of the pensions are covered when $E / R$ ratio is 1,20 , it can be concluded, keeping the share of an average pension in GDP per capita constant, a self sufficient generation solidarity fund in Croatia could be achieved when $E / R$ would have been: $E / R=1,20 / 0,563=2,13$. Knowing the budget volume and the shortage of the pension fund, it is found that on average $9,7 \%$ of budget is spent on the coverage of the shortage in the pension fund (ibidem). Keeping the same proportion of the state budget in GDP, each percentage point of shortage of pension funds accounts for $9,7 \%$ / $(100 \%-56,3 \%)=0,222 \%$ of the state budget being transferred to the pension fund.

Table 6: GDP, budget, pensions paid, pensions insurance and pension fund shortage in Croatia, 2009 - 2018 


\begin{tabular}{|c|c|c|c|c|c|c|c|c|}
\hline year & 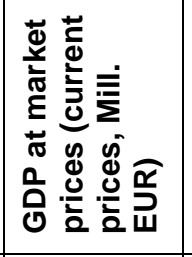 & 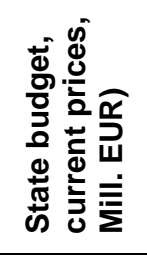 & 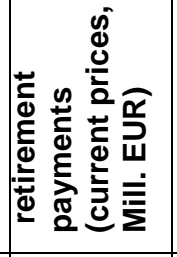 & 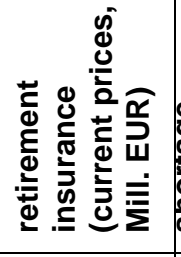 & 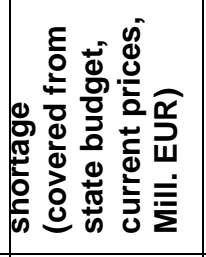 & 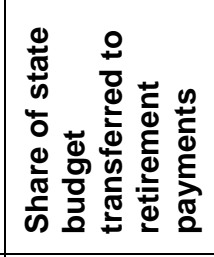 & 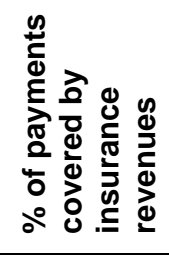 & 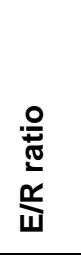 \\
\hline 2009 & 45.145 & 21.805 & 4.687 & 2.703 & 1.984 & $9,1 \%$ & $57,7 \%$ & 1,32 \\
\hline 2010 & 45.156 & 21.675 & 4.787 & 2.629 & 2.158 & $10,0 \%$ & $54,9 \%$ & 1,24 \\
\hline 2011 & 44.826 & 21.740 & 4.701 & 2.593 & 2.109 & $9,7 \%$ & $55,1 \%$ & 1,22 \\
\hline 2012 & 43.983 & 21.024 & 4.682 & 2.566 & 2.116 & $10,1 \%$ & $54,8 \%$ & 1,18 \\
\hline 2013 & 43.779 & 20.839 & 4.761 & 2.588 & 2.174 & $10,4 \%$ & $54,3 \%$ & 1,15 \\
\hline 2014 & 43.431 & 20.890 & 4.767 & 2.948 & 1.819 & $8,7 \%$ & $61,8 \%$ & 1,15 \\
\hline 2015 & 44.606 & 21.545 & 4.820 & 2.733 & 2.087 & $9,7 \%$ & $56,7 \%$ & 1,16 \\
\hline 2016 & 46.640 & 22.060 & 4.888 & 2.675 & 2.213 & $10,0 \%$ & $54,7 \%$ & 1,17 \\
\hline 2017 & 48.990 & 22.192 & 5.050 & 2.827 & 2.223 & $10,0 \%$ & $56,0 \%$ & 1,20 \\
\hline 2018 & 51.468 & 23.881 & 5.245 & 2.959 & 2.286 & $9,6 \%$ & $56,4 \%$ & 1,22 \\
\hline $\begin{array}{l}\text { decade } \\
\text { average }\end{array}$ & 45.802 & 21.765 & 4.839 & 2.722 & 21.169 & $9,7 \%$ & $56,3 \%$ & 1,20 \\
\hline
\end{tabular}

Source - Own calculation based on data from Eurostat and Hrvatski zavod za mirovinsko osiguranje

After obtaining a self-sufficient level of $E / R$ ratio (assuming the current level of the average pension in GDP per capita, which is rather fixed and the share of budget in GDP), one can combine projections from Section 2 to project the extent of the budget intervention (coverage) in the pension fund in Croatia up to 2053 (Table 7).

Table 7: Simulation of the Croatian pension fund shortage in Sustainable and Adaptive scenarios for years $2018-2053$

\begin{tabular}{|c|c|c|c|c|c|c|c|c|c|}
\hline Scenaric & Variable & 2018 & 2023 & 2028 & 2033 & 2038 & 2043 & 2048 & 2053 \\
\hline \multirow{4}{*}{ 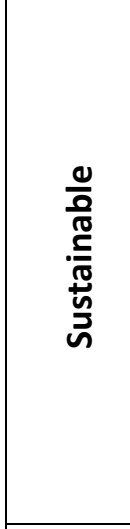 } & Population & 4.190 .669 & 4.139 .740 & 4.122 .592 & 4.125 .526 & 4.120 .932 & 4.114 .265 & 4.114 .198 & 4.126 .640 \\
\hline & E/R ratio & 1,20 & 1,20 & 1,13 & 1,07 & 1,05 & 1,12 & 1,16 & 1,19 \\
\hline & $\begin{array}{l}\text { retirement } \\
\text { insurance/p } \\
\text { ensions } \\
\text { paid ratio }\end{array}$ & $56,3 \%$ & $56,2 \%$ & $52,8 \%$ & $50,1 \%$ & $49,5 \%$ & $52,5 \%$ & $54,4 \%$ & $56,0 \%$ \\
\hline & $\begin{array}{l}\text { share of } \\
\text { budget } \\
\text { spent for } \\
\text { pension } \\
\text { fund } \\
\text { coverage }\end{array}$ & $9,7 \%$ & $9,7 \%$ & $10,5 \%$ & $11,1 \%$ & $11,2 \%$ & $10,5 \%$ & $10,1 \%$ & $9,8 \%$ \\
\hline \multirow{3}{*}{$\begin{array}{l}\frac{1}{2} \\
\frac{0}{0} \\
\frac{\pi}{0}\end{array}$} & Population & 4.190 .669 & 3.941 .836 & 3.725.917 & 3.528 .699 & 3.322 .277 & 3.112 .490 & 2.908 .529 & 2.716 .686 \\
\hline & $E / R$ ratio & 1,20 & 1,17 & 1,08 & 1,01 & 0,98 & 0,97 & 0,94 & 0,91 \\
\hline & $\begin{array}{l}\text { retirement } \\
\text { insurance/p } \\
\text { ensions } \\
\text { paid ratio }\end{array}$ & $56,3 \%$ & $55,1 \%$ & $50,8 \%$ & $47,3 \%$ & $46,1 \%$ & $45,7 \%$ & $44,3 \%$ & \\
\hline
\end{tabular}




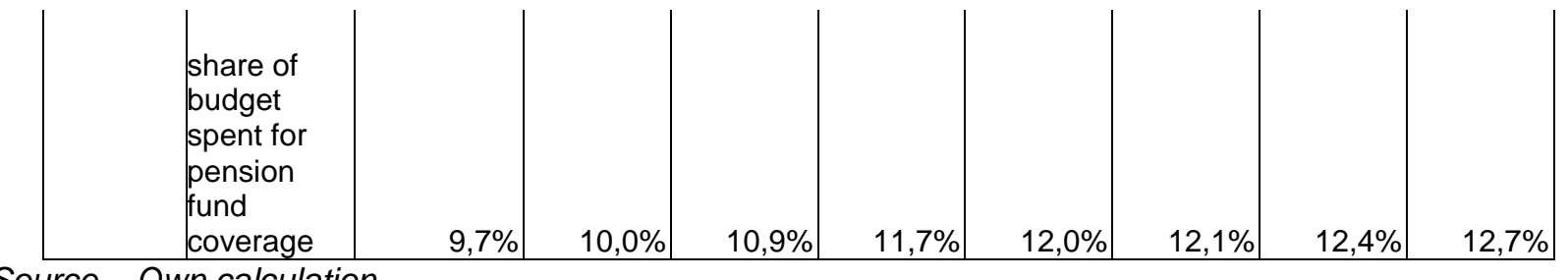

Source - Own calculation

In Table 7 a ratio of pension fund revenues and expenses (retirement insurance / pensions paid ratio) is calculated using a previous estimate of a self-sufficient $E / R$ ratio being 2,13: $E / R$ ratio is divided with 2,13 expressed as a percentage. Budget intervention is calculated using a previously calculated relation between pension fund percentage shortage and budget intervention to pension fund: 0,222 . Therefore this value is $(100 \%$ - retirement insurance/pensions paid ratio) $\times 0,222$.

These calculation are made for two scenarios, adaptive and sustainable, like in Section 2. Different effects and consequences are shown on the Figure 5.

Figure 5: Croatian pension fund revenues/expenses ratio and its requirement for state budget intervention (in \% of state budget), 2018 - 2053

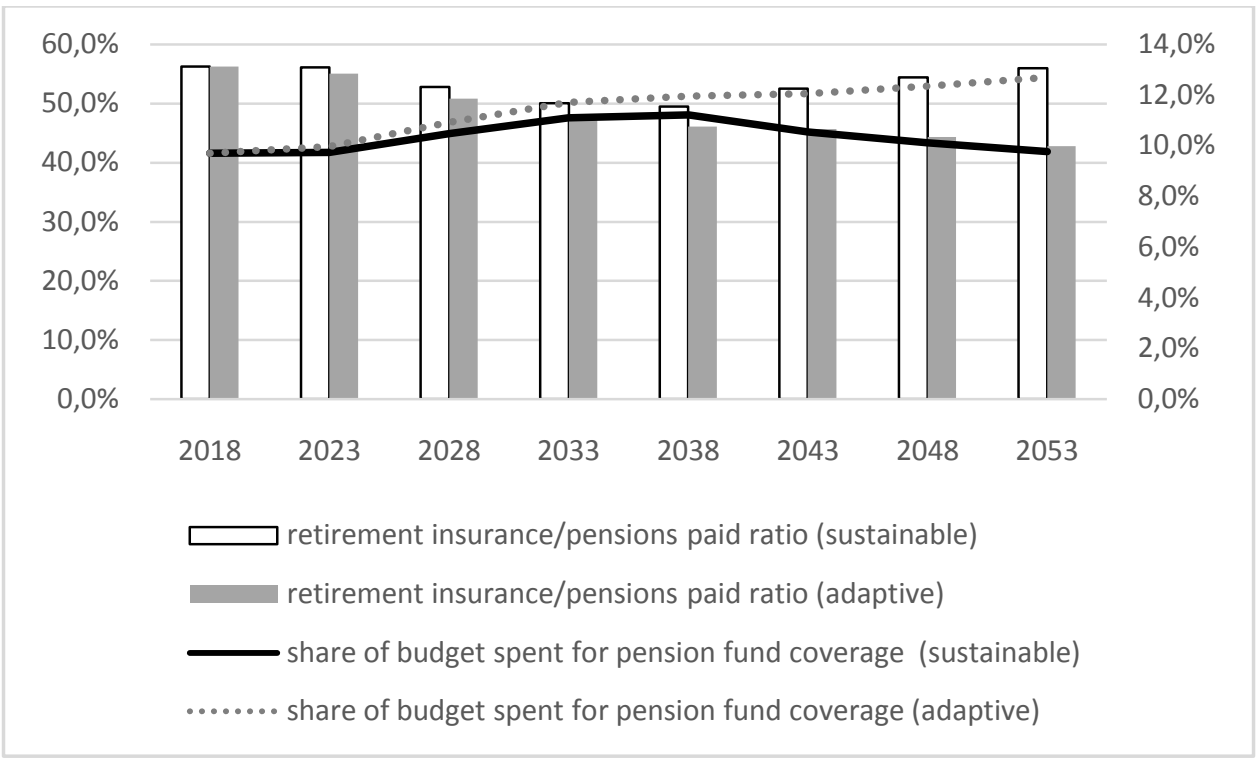

Source - Own calculation

Figure 5 reveals that even in the sustainable scenario, Croatian pension fund would face a drop in the self-sufficiency, but in two decades one could expect the upswing (bars, left axis). By that time a need for a state budget intervention would stop rising and start falling. By 2053 it would match the one from today but continue dropping. In the adaptive scenario, which implies current levels of emigration and birth rate, self-sustainability of the pension fund drops down continuously, being at only $42,8 \%$ in 2053 . Demand for state budget funds would keep rising, claiming high $12,7 \%$ of the budget (1/8), or a significant change in the welfare of retired people in both terms of pension volume and the age of retirement (Fredriksen, Stølen, 2005). However, Stauvermann and Kumar (2016) in their overlapping generation model show that such detrimental scenarios are not about to come true since young generations increase productivity through more intense use of human 
capital. Therefore in future analyses stocks of human capital in Croatia could be added as a variable to the model to try to make the model more plastic.

\section{Labour substitution: growth accounting simulation}

Even in the worst case scenario there is a way to maintain the system, yet very costly, by substitution of labour with capital and technology. In the following part of the paper a growth accounting based simulation is made (for details see Gallardo-Sejas et al., 2006, and Acemoglu, 2009).

According to the neoclassical theory, production depends on the levels of capital and labour. Hence, if projections show that labour is to decline, then the capital should increase. The only way to increase the level of capital is through investment, which is the part of gross domestic product. The aim of this analysis is to show what is the amount by which investment-GDP ratio should increase in order to maintain some minimum level of GDP growth, say, $3 \%$.

One assumes the basic Cobb-Douglas production function:

$$
Y=A K^{\kappa} L^{\lambda}
$$

where $\mathrm{Y}$ represents a gross domestic product, $\mathrm{A}$ is a total factor productivity, $\mathrm{K}$ is the amount of capital, $L$ is the amount of labour and $k$ is a contribution of capital. Contribution of labour is $\lambda$.

Capital is accumulation of investments discounted by a depreciation factor $\delta$ :

$$
K=\sum_{t=0}^{-\infty} \frac{I_{t}}{(1+\delta)^{-t}}
$$

Let $i$ be an investment/output ratio which shows a proportion of output that is invested:

$$
i=\frac{I}{Y}
$$

When simplified: $I_{t} \approx I$ then a sum of geometric sequence formula can be applied:

$$
K=\sum_{t=0}^{-\infty} \frac{I_{t}}{(1+\delta)^{-t}}=\frac{I}{\delta}
$$

Stubbing (3) in (4) one gets:

$$
K=\frac{i Y}{\delta}
$$

Stubbing (5) in (1) one gets:

$$
Y=A\left(\frac{i Y}{\delta}\right)^{\kappa} L^{\lambda}
$$

Taking natural logarithm one gets:

$$
\ln Y=\ln A+\kappa \ln i+\kappa \ln Y-\kappa \ln \delta+\lambda \ln L
$$

Applying a time differential one gets:

$$
\dot{Y}=\dot{A}+\kappa(\dot{i})+\kappa \dot{Y}+\lambda \dot{L}
$$

where variables with dots are growth rates of these variables. For simplicity reason, in the following part of this analysis more common symbols will be used:

$$
g_{Y} \equiv \dot{Y} ; g_{i} \equiv(\dot{i}) ; g_{L} \equiv \dot{L}
$$

Rearranging (8) and applying (9) one gets:

$$
g_{i}=\frac{1-\kappa}{\kappa} q_{Y}-\frac{g_{A}}{\kappa}-\frac{\lambda g_{L}}{\kappa}
$$


For example, under a common assumption that $\kappa=\frac{1}{3}$ and $\lambda=\frac{2}{3}$, a moderate GDP growth rate of $3 \%$ and assuming a decline in the workforce of $1 \%$ (Herceg, Vuksanović Herceg, Škuflić, 2018) one gets:

$$
g_{i}=8-3 g_{A}
$$

Since in the above case labour is twice as contributing as capital, share of investments in output should rise 2 times faster than the labour force falls. Therefore, under no technology improvement, share of investments in output should increase by $8 \%$ to maintain $3 \%$ GDP growth rate and a population decline of $1 \%$.

\section{Conclusion}

A generation solidarity pension funds are always at risk if a population starts aging, either because of a low fertility rate, high death rate of migration tendencies. Croatian total fertility rate (number of children per woman) fell below replacement level 6 decades ago and now consequences are as follows: one retired person is matched with only 1,2 employed; pension fund is able to finance pensions for only $56 \%$ of retired, and the rest of the funds are covered from a Croatian state budget, which amount to even $10 \%$ of all the budget assets.

Croatia has faced many emigration waves in the last 130 years, the last being the strongest recorded. It was triggered by the EU accession and peaked at $0.9 \%$ in 2017 , but slowed down to $0,33 \%$ in 2018. Emigration is even more dangerous for an economy because a country invests in education of young people, but part of them emigrates without repaying the costs of their education and health care, up to date covered by the state which an emigrant has left behind.

In order to determine the future consequences of the adverse population trends, projections are made using a simulation based on historic death rates per age group, net emigration rates per age group, a birth rate which would be supplied to the model and current number of people in Croatia per age group. It is obtained that in order to at least maintain current population level, a $1,5 \%$ birth rate would be required, or a net immigration rate to cover for birth rate shortage. Even under that scenario, an employed per retired ratio would start to improve in 20 years from now and match the one currently present in 35 years from now. In that case the government budget could expect to have lesser weight of a pension fund shortage covering in 25 years from now.

In a pessimistic scenario, based on the current data for birth rate and net emigration rate, population falls below 3 million in 30 years from now. By that time there would be more retired than employed and $1 / 8^{\text {th }}$ of the budget would be used to cover a shortage of the pension fund.

A growth accounting view sheds a light even in that scenario, showing that lack of labour could be substituted by capital deepening, but at a great cost: for each $1 \%$ fall in labour force, a share of investments in GDP should increase by $8 \%$.

This paper uses many projections and assumptions which do not aim to precisely predict the future, but only to give a glance at what could happen if an adequate demographic and economic measures would not take place. It also shows how challenging it will be for future governments to maintain steady growth under such conditions. 


\section{References}

Acemoglu, D. (2009): Introduction to Modern Economic Growth, San Francisco: Princeton Press

Akrap, A. (2005): Demografsko stanje, trendovi, perspektive i nužnost provođenja populacijske politike u Republici Hrvatskoj, Hrvatski časopis za javno zdravstvo (1845-3082) Vol I (2005), Br. 2; 2-12

Aubin, J. P., Bonneuil, N., Maurin, F., \& Saint-Pierre, P. (2001). Viability of pay-as-you-go systems. Journal of Evolutionary Economics, 11(5), 555-571.

Bongaarts, J. (2004). Population aging and the rising cost of public pensions. Population and Development Review, 30(1), 1-23.

Börsch-Supan, A. (2003). Labor market effects of population aging. Labour, 17, 5-44.

Castles, S., De Haas, H., \& Miller, M. J. (2013). The age of migration: International population movements in the modern world. Palgrave Macmillan.

Chand, S.K., Jaeger, A., 1996. Aging populations and public pension schemes. Occasional Paper 147, International Monetary Fund, Washington, DC.

Državni zavod za statistiku (2018). Migracija stanovništva Republike Hrvatske, Priopćenje, br. 7.1.2., godina LX.

Državni zavod za statistiku (2018). Žene i muškarci u Hrvatskoj.

Fanti, L., \& Gori, L. (2012). Fertility and PAYG pensions in the overlapping generations model. Journal of Population Economics, 25(3), 955-961.

Favell, A. (2008). The new face of East-West migration in Europe. Journal of ethnic and migration studies, 34(5), 701-716.

Fredriksen, D., \& Stølen, N. M. (2005). Effects of demographic development, labour supply and pension reforms on the future pension burden. Discussion Papers 418, Statistics Norway, Research Department.

Frejka, T., Sobotka, T., (2008): Fertility in Europe: Diverse, delayed and below replacement, Special collection 7: Childbearing Trends and Policies in Europe, Demographic Research, Vol 19.

Gallardo-Sejas, H., Pareja, S. G., Llorca-Vivero, R., \& Martínez-Serrano, J. A. (2006). Determinants of European immigration: a cross-country analysis. Applied Economics Letters, 13(12), 769-773.

Helpman, E.(2004), The Mystery of Economic Growth, Cambridge, MA:Harvard University Press Holzmann, R. (2005). Demographic alternatives for aging industrial countries: increased total fertility rate, labor force participation, or immigration. Institute for the Study of Labor Discussion Paper.

Hrvatski zavod za mirovinsko osiguranje (2007). Izvješće o financijskom poslovanju hrvatskog zavoda za mirovinsko osiguranje za 2006. godinu.

Hrvatski zavod za mirovinsko osiguranje (2008). Izvješće o financijskom poslovanju hrvatskog zavoda za mirovinsko osiguranje za 2007. godinu.

Hrvatski zavod za mirovinsko osiguranje (2009). Izvješće o financijskom poslovanju hrvatskog zavoda za mirovinsko osiguranje za 2008. godinu.

Hrvatski zavod za mirovinsko osiguranje (2010). Izvješće o financijskom poslovanju hrvatskog zavoda za mirovinsko osiguranje za 2009. godinu.

Hrvatski zavod za mirovinsko osiguranje (2011). Izvješće o financijskom poslovanju hrvatskog zavoda za mirovinsko osiguranje za 2010. godinu. 
Hrvatski zavod za mirovinsko osiguranje (2012). Izvješće o financijskom poslovanju hrvatskog zavoda za mirovinsko osiguranje za 2011. godinu.

Hrvatski zavod za mirovinsko osiguranje (2013). Izvješće o financijskom poslovanju hrvatskog zavoda za mirovinsko osiguranje za 2012. godinu.

Hrvatski zavod za mirovinsko osiguranje (2014). Izvješće o financijskom poslovanju hrvatskog zavoda za mirovinsko osiguranje za 2013. godinu.

Hrvatski zavod za mirovinsko osiguranje (2015). Izvješće o financijskom poslovanju hrvatskog zavoda za mirovinsko osiguranje za 2014. godinu.

Hrvatski zavod za mirovinsko osiguranje (2016). Izvješće o financijskom poslovanju hrvatskog zavoda za mirovinsko osiguranje za 2015. godinu.

Hrvatski zavod za mirovinsko osiguranje (2017). Financijski plan hrvatskog zavoda za mirovinsko osiguranje za 2018. godinu.

Hrvatski zavod za mirovinsko osiguranje (2017). Izvješće o financijskom poslovanju hrvatskog zavoda za mirovinsko osiguranje za 2016. godinu.

Hrvatski zavod za mirovinsko osiguranje (2018). Izvješće o financijskom poslovanju hrvatskog zavoda za mirovinsko osiguranje za 2017. godinu.

Institut national d'etudes demographiques, Base de donnee des pays developpes, www.ined.fr/fr/pop_chiffres/pays_developpes/base_pays_developpes/ [Accessed 11.2.2011]

Mayda, A. M. (2010). International migration: A panel data analysis of the determinants of bilateral flows. Journal of Population Economics, 23(4), 1249-1274.

Stauvermann, P. J., \& Kumar, R. R. (2016). Sustainability of a pay-as-you-go pension system in a small open economy with ageing, human capital and endogenous fertility. Metroeconomica, 67(1), 2-20.

Wang, P., Yip, C. K., \& Scotese, C. A. (1994). Fertility choice and economic growth: Theory and evidence. The Review of Economics and Statistics, 255-266.

Wertheimer-Baletić, A. 2017. Demografska teorija, razvoj stanovništva Hrvatske I populacijska politika. Zagreb: Meridijan. 